\title{
Bazı Ekmeklik Buğday (Triticum aestivum L.) Genotiplerinin Agromorfolojik Özellikleri Bakımından Biplot, Kümeleme ve Path Analizi Yöntemleri ile Değerlendirilmesi
}

\author{
Fatih Demirel $^{1 *}$, Ahmet Metin Kumlay², Bünyamin Yıldırım ${ }^{3}$ \\ 1* Iğdır Üniversitesi, Ziraat Fakültesi, Tarla Bitkileri Bölümü, Iğdır, Türkiye, (ORCID: 0000-0002-6846-8422), drfdemirel@gmail.com \\ ${ }^{2}$ Iğdır Üniversitesi, Ziraat Fakültesi, Tarla Bitkileri Bölümü, Iğdır, Türkiye (ORCID: 0000-0001-9765-8674), akumlay@hotmail.com \\ ${ }^{3}$ Iğdır Üniversitesi, Ziraat Fakültesi, Tarla Bitkileri Bölümü, Iğdır, Türkiye (ORCID: 0000-0003-2463-6989), byildirim71@gmail.com
}

(İlk Geliş Tarihi 26 Ocak 2021 ve Kabul Tarihi 28 Mart 2021)

(DOI: $10.31590 /$ ejosat.868789)

\begin{abstract}
ATIF/REFERENCE: Demirel, F., Kumlay, A. M. \& Yıldırım, B. (2021). Bazı Ekmeklik Buğday (Triticum aestivum L.) Genotiplerinin Agromorfolojik Özellikleri Bakımından Biplot, Kümeleme ve Path Analizi Yöntemleri ile Değerlendirilmesi. Avrupa Bilim ve Teknoloji Dergisi, (23), 304-311.

$\ddot{O} \mathbf{z}$

Bu çalışmada materyal olarak 21 adet ekmeklik buğday (T. aestivum L.) genotipi ile tescilli 2 adet ekmeklik buğday çeşidi (Ahmetağa ve Cemre) kullanılmıştır. Yazlık olarak ekilen 23 adet genotipin başakta dane sayısı (DS), başakta dane verimi (TV), biyolojik verim (BV), hasat indeksi (HI), bitki boyu (BB) ve başak uzunluğu (BU) özellikleri incelenmiştir. İrdelenen tarımsal karakterler arasındaki ilişkiler path, biplot ve korelasyon analizleriyle değerlendirilmiştir. Genotipler arası ilişkiyi belirlemek için kümeleme (Aglomeratif hiyerarşik kümeleme) analizi uygulanmıştır. Path analizi sonucunda TV'ne doğrudan etki gösteren BU'nun katkı oranının \%42.63 olduğu saptanmıştır. Biplot analizi sonucunda F1 ve F2'nin toplam varyasyonu açıklama oranının \%73.32 olduğu belirlenmiştir. Dane verimi yönünden seleksiyon için P13, P14 ve P19 numaralı genotiplerin öne çıktığı tespit edilmiştir. İncelenen genotiplerin 1slah materyali olarak kullanılabilme etkinlikleri ortaya konulmuştur. Olumlu yönde etkili olan karakterlerin seleksiyon kriteri olarak kullanılabileceği sonucuna varılmıştır.
\end{abstract}

Anahtar Kelimeler: Buğday, Genotip, Biplot analizi, Kümeleme analizi, Path analizi.

\section{Evaluation of Agromorphological Characteristics of Some Bread Wheat (Triticum aestivum L.) Genotypes by Biplot, Clustering and Path Analysis Methods}

\begin{abstract}
In this study, 21 bread wheat ( $T$. aestivum L.) genotypes and 2 registered bread varieties (Ahmetaga and Cemre) were used as material. The characteristics of 23 genotypes planted as summer cottage number of grain (DS), grain yield (TV), biological yield $(\mathrm{BV})$, harvest index (HI), plant height (BB) and spike length (BU) were investigated. The relationships between the discussed agricultural characters were evaluated by path, biplot and correlation analysis. Cluster analysis was applied to determine the relationship between genotypes. As a result of the path analysis, it was determined that the contribution rate of BU which has a direct effect on TV was $42.63 \%$. As a result of the biplot analysis, it was determined that the approval of disclosing the total variation of F1 and F2 was $73.32 \%$. In terms of grain yield, it was determined that the genotypes P13, P14 and P19 stand out for selection. The efficiency of the analyzed genotypes as breeding material has been revealed. It was concluded that the characters that are positively effective can be used as selection criteria.
\end{abstract}

Keywords: Wheat, Genotype, Biplot analysis, Clustering analysis, Path analysis.

*Sorumlu Yazar: drfdemirel@gmail.com 


\section{Giriş}

Buğdayın orijininin Güneybatı Asya olduğu ve Türkiye, Irak, Suriye ve Kafkasya'da yabani türlerinin bulunduğu ve buraların buğdayın gen merkezi olarak kabul edildiği bildirilmiştir (Kırtok, 1997). Buğday'ın ilk kez Türkiye'nin de yer aldığ 1 "verimli hilal" olarak adlandırılan alanda kültüre alındığı birçok araştırıcı tarafından kabul görmüştür (Heun ve ark., 1997; Lev-Yadun ve ark., 2000). Buğday, dünyada olduğu gibi Türkiye'de de önemli besin kaynağı konumunda olan bir tahıl bitkisidir.

Buğdayın dane verimi karmaşık bir özelliktir ve katkıda bulunan birkaç bileşenin ürünüdür (Dağüstü, 2008). Buğdayda dane verimi, gelişimi sırasında meydana gelen bazı önemli fizyolojik özelliklerin (başakcık sayısı, başak ağırlığı ve başakta dane sayısı) etkisi altındadır. Bu verim özelliklerinin buğday dane verimi üzerinde doğrudan ve dolaylı etkileri, çoğunlukla bitki gelişme evresine ve yetiştirme türüne bağlıdır (Okuyama ve ark., 2004). Korelasyon katsayıları, genotiplerin farklı özellikleri üzerindeki etkilerinin bilgisi ile verime katkıda bulunan özelliklerin dane verimi ile ilişki derecesini belirlemede önemli rol oynamaktadır. Bu analiz, farklı özellikler arasındaki ilişkileri ölçmek ve etkinin verime yansıtılıp yansıtılmadı̆̆ını göstermek için bir araç sağlayan güvenilir bir istatistiksel yöntemdir (Sabaghnia ve Janmohammadi, 2014).

Yetiştirme programlarına ilişkin verilerin etkili bir şekilde yorumlanması, bitki ıslahının tüm aşamalarında, özellikle sadece verim bileşenlerinin seçilmesinin mümkün olduğu durumlarda önemlidir. Veri yapısının anlaşılması için çeşitli yöntemler kullanılmıştır. Bu yöntemler genel uygunluk açısından farklılık gösterebilir; farklı yöntemler genellikle belirli bir veri kümesi için benzer sonuçlara götürür. Biplot, çeşitlerin ve çevrenin etkilerini eşzamanlı olarak gösteren bir çizimdir. GGE biplot (genotip "G" ve genotip-çevre etkileşimi "GE”), birden çok özelliğe sahip genotiplerin her tür iki yönlü veri kümesi için de kullanılabilir (Sabaghnia ve Janmohammadi, 2014).
İkiden farklı değişkenin ilişkisini açıklamada path analizi kullanılmaktadır. Path katsayıları incelenen değişkenler arasındaki ilişkiyi doğrudan ve dolaylı etkileri ile birlikte inceleme firsatı vermektedir. Path katsayıları sayesinde sonucu etkileyen bağımsız değişkenlerin doğrudan ve dolaylı etki miktarlarının oranları belirlenebilmektedir (Orhan ve Kaşıkçı, 2002).

Bu çalışmada, 23 adet buğday genotipinde dane verimine etki edebilecek özellikler arası (DS: Başakta dane sayısı, TV: Dane verimi, BV: Biyolojik verim, Hİ: Hasat indeksi, BB: Bitki boyu, BU: Başak uzunluğu) ilişkilerin saptanması ve dane veriminde etkili değişkenlerin Iğdır ili koşullarında yetiştirilen buğdaylarda belirlenmesi amaçlanmıştır.

\section{Materyal ve Metot}

\subsection{Materyal}

Araştırmada materyal olarak 21 ekmeklik buğday (Triticum aestivum L.) genotipi ve 2 tescilli ekmeklik buğday çeşidi (Ahmetağa ve Cemre) olmak üzere toplamda 23 ekmeklik buğday genotipi kullanılmıştır. 21 genotip Kahramanmaraş, Konya, Aksaray, Kayseri, Kastamonu, Yozgat, Sivas ve Adıyaman illerinden toplanmış olup Iğdır ilinde 2017 yıllında ekimleri yapılmıştır.

\subsection{Araştırma Alanı İklim Özellikleri}

Araştırmanın yürütüldüğü Iğdır iline ait Mart-Ağustos aylarının ilişkin Meteoroloji Genel Müdürlüğü verilerine göre toplam yağış miktarı $95.7 \mathrm{~mm}$ olmuştur. Iğdır ilinde 2017 yılında uzun yıllar ortalamasına $(165.9 \mathrm{~mm})$ göre daha düşük yağ1ş gerçekleşmiştir. Denemenin yürütüldüğü yetiştirme sezonunda uzun yıllar ortalama sıcaklığı $18.6^{\circ} \mathrm{C}$ iken 2017 yılı ortalama sıcaklığ $19.8^{\circ} \mathrm{C}$ olarak kaydedilmiştir. Nispi nem oranı verilerine göre 2017 yetiştirme dönemi nispi nem oranı $(\% 48.4)$ ile uzun yıllar ortalamasında $(\% 48.8)$ benzerlik olduğu görülmüştür (Çizelge 1).

Çizelge 1. Denemenin yürütüldüğü 2017 yılı ile uzun yıllar ortalamasına (UYO) ait bazı iklim verileri.

\begin{tabular}{|c|c|c|c|c|c|c|c|c|}
\hline \multirow{2}{*}{ İklim faktörleri } & \multirow{2}{*}{ Yil } & \multicolumn{7}{|c|}{ Aylar } \\
\hline & & Mart & Nisan & Mayıs & Haziran & Temmuz & Ăgustos & Toplam/Ortalama \\
\hline \multirow{2}{*}{ Yağış (mm) } & 2017 & 8.5 & 14.5 & 51.7 & 6.9 & 6.1 & 8.0 & 95.7 \\
\hline & UYO & 21.9 & 37.4 & 49.4 & 33.1 & 14.5 & 9.6 & 165.9 \\
\hline \multirow{2}{*}{ Sicaklık $\left({ }^{\circ} \mathrm{C}\right)$} & 2017 & 6.7 & 13.4 & 18.6 & 24.2 & 28 & 27.8 & 19.8 \\
\hline & UYO & 6.9 & 13.4 & 17.5 & 22.3 & 26.2 & 25.6 & 18.6 \\
\hline \multirow{2}{*}{ Nispi nem (\%) } & 2017 & 59.9 & 47.2 & 54.0 & 42.9 & 41.9 & 44.3 & 48.4 \\
\hline & UYO & 52.2 & 49.9 & 51.5 & 47.3 & 45.3 & 47.1 & 48.8 \\
\hline
\end{tabular}

\subsection{Araștırma Alanı Toprak Özellikleri}

Araştırma alanının farklı konumlarından alınan 0-20 cm derinliğindeki toprağın killi-tınllı bünyeye sahip olduğu, toprak pH'sının 8.6 (şiddetli alkali) olduğu, kireç $\left(\mathrm{CaCO}_{3}\right)$ miktarının $\% 22.25$, organik madde miktarının \%1.2, azot miktarının $(\mathrm{N})$ $\% 0.06$, fosfor miktarının 51.5 ppm, potasyum miktarının $\left(\mathrm{K}_{2} \mathrm{O}\right)$ $851.5 \mathrm{ppm}$ ve elektriksel iletkenlik değerinin $1.37 \mathrm{dS} \mathrm{m}^{-1}$ olduğu belirlenmiştir.

\subsection{Metot}

Araştırmanın tarla denemesi Iğdır Üniversitesi Tarımsal Uygulama ve Araştırma arazisinde 2017 vejetasyon döneminde yürütülmüştür. Araştırmada buğday genotiplerinin, Mart ayında tesadüf blokları deneme desenine göre 3 blok (her blok $68.5 \times 2$ m) olarak $2.5 \times 2$ m'lik parsellere ekimi yapılmıştır. Ekimle birlikte $3 \mathrm{~kg} \mathrm{da}^{-1}$ saf azot (N) ve $6 \mathrm{~kg} \mathrm{da}^{-1}$ saf fosfor $\left(\mathrm{P}_{2} \mathrm{O}_{5}\right)$, kardeşlenme döneminde ise $3 \mathrm{~kg} \mathrm{da}^{-1}$ saf azot (N) olacak şekilde gübreleme işlemleri yapılmıştır. Araştırmada ele alınan Başakta dane sayısı (DS), başakta dane verimi (TV), biyolojik verim 
(BV), hasat indeksi (HI), bitki boyu (BB), başak uzunluğu (BU) gibi verilerin elde edilmesinde; Tosun ve Yurtman (1973) ve Tugay (1978)'ın belirttikleri yöntemlerden yararlanılmıştır. Elde edilen veriler XLSTAT paket programı kullanılarak analiz edilmiştir (Addinsoft, 2015).

\section{Araştırma Sonuçları ve Tartışma}

Buğday genotiplerinde incelenen özelliklerin ortalama değerleri ve Duncan gruplaması Çizelge 2'de gösterilmiştir. Ayrıca çizelgede, incelenen buğday genotipleri arasında bitki boyu, başak uzunluğu, başakta dane sayısı, başakta dane verimi, biyolojik verim ve hasat indeksi yönünden değişim gösteren verilerin istatistiksel olarak çok önemli $* \mathrm{p}<0.0001$ olduğu tespit edilmiştir.

Çizelge 2. Buğday genotiplerinde incelenen özelliklerin ortalama değerleri.

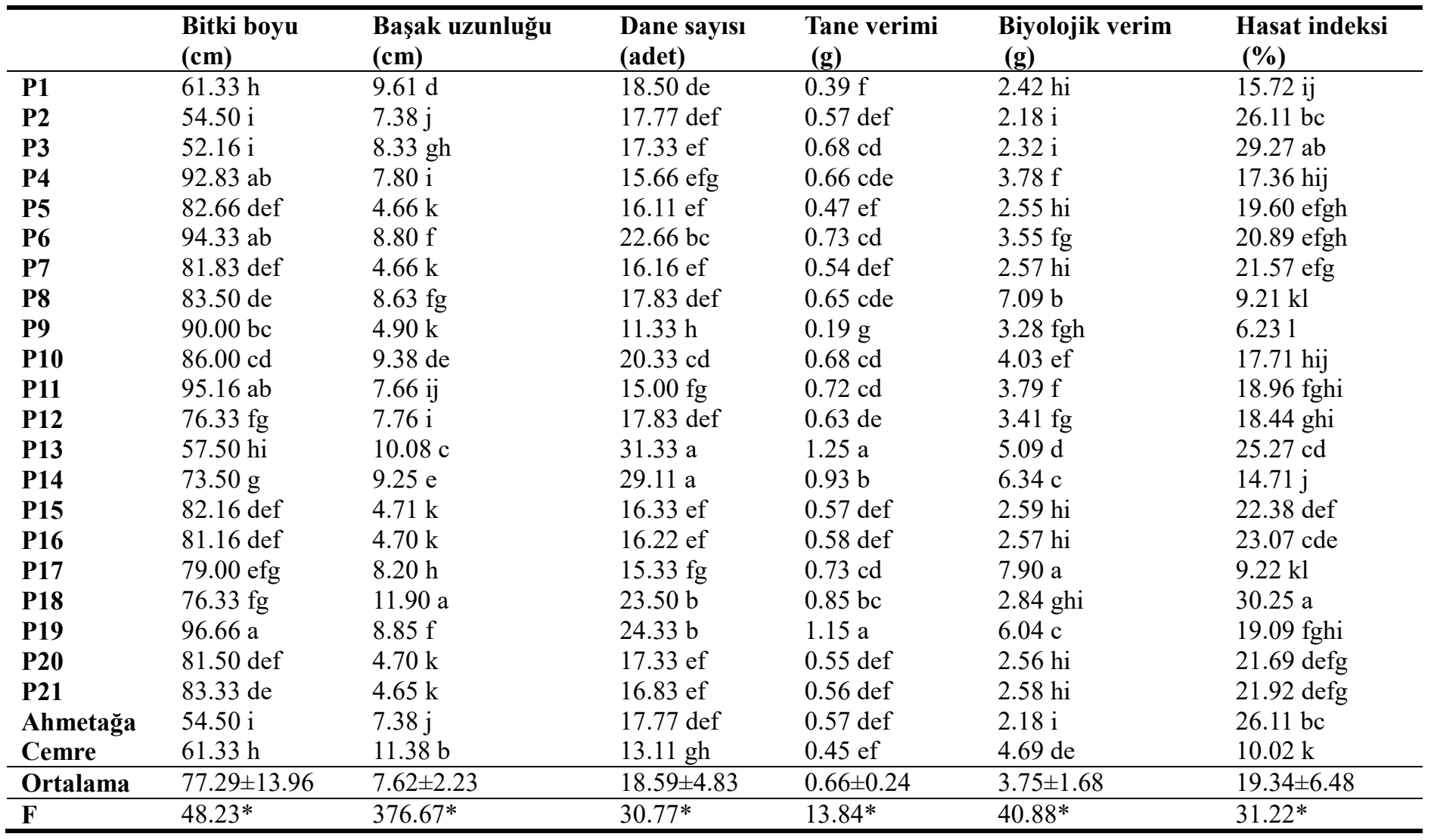

\subsection{Bitki Boyu}

İncelenen buğday genotiplerinde ortalama bitki boyunun 52.16 ile $96.66 \mathrm{~cm}$ arasında değiştiği ve ortalama bitki boyunun ise $77.29 \mathrm{~cm}$ olduğu saptanmıştır. En kısa bitki boyu P3 numaralı genotipte gözlenirken en uzun bitki boyu ise P19 numaralı genotipte gözlemlenmiştir. Ahmetağa ve Cemre çeşitlerinin ortalama bitki boyunun bütün genotiplerin bitki boyu ortalamalarına göre daha düşük olduğu tespit edilmiştir (Çizelge 2). Çalışmadaki bitki boyu bulgularının, Aydın ve ark. (2005)'nin Samsun ve Amasya bölgelerinde yürüttükleri çalışmaya ait ortalama bitki boyu $(68.1-95.6 \mathrm{~cm})$ değerleriyle, Aydoğan ve Soylu (2017)'nun 14 ekmeklik çeşidini araştırdıkları çalışmadaki bitki boyu $(79.5-108.2 \mathrm{~cm})$ değerleriyle ve Çağlar ve ark. (2005)'nin 25 ekmeklik çeşidini inceledikleri çalışmadaki bitki boyu $(72.5-99.3 \mathrm{~cm})$ değerleri ile kısmen uyumlu olduğu, bazı genotiplere ait bitki boylarının ise düşük olduğu belirlenmiştir.

\subsection{Başak Uzunluğu}

İncelenen buğday genotiplerinin ortalama başak uzunluğu değerleri 4.65 ile $11.9 \mathrm{~cm}$ arasında değişmiş olup ortalama başak uzunluğunun ise $7.62 \mathrm{~cm}$ olduğu saptanmıştır. En kısa başak uzunluğu P21 numaralı genotipte gözlenirken en uzun başak uzunluğunun ise P18 numaralı genotipe ait olduğu gözlemlenmiştir. Ahmetağa çeşidinin ortalama başak uzunluğunun bütün genotiplerin başak uzunluğu ortalamasına yakın değerde olduğu, fakat Cemre çeşidinin başak uzunluğunun ise diğer genotilere göre daha yüksek olduğu tespit edilmiştir (Çizelge 2). Çalışmadaki başak uzunluğu bulgularının, Özen ve Akman (2015)'ın 14 buğday çeşidini inceledikleri çalışmadaki ortalama başak uzunluğu (8.3-10.4 cm) değerleriyle, Aydoğan ve Soylu (2017)'nun 14 ekmeklik çeşidini araştırdıkları çalışmadaki başak uzunluğu $(8.87-11.10 \mathrm{~cm})$ değerleriyle ve Naneli ve ark. (2015)'nın 25 ekmeklik buğday çeşidini inceledikleri çalışmadaki başak uzunluğu $(8-9.87 \mathrm{~cm})$ değerleri ile kısmen uyumlu olduğu, bazı genotiplere ait başak uzunluklarının ise literatürdeki değerlerden düşük olduğu tespit edilmiştir.

\subsection{Başakta Dane Sayısı}

İncelenen buğday genotiplerinde ortalama dane sayıs1 11.33 ile 31.33 adet arasında değişmiş olup genotiplerin ortalama dane sayısının ise 18.54 adet olduğu saptanmıştır. En az dane sayısı P9 numaralı genotipte gözlenirken en çok dane sayısının ise P13 numaralı genotipe ait olduğu gözlemlenmiştir. Ahmetağa çeşidinin ortalama dane sayısı, bütün genotiplere ait dane sayısı 
ortalamasına göre yakın değerde, Cemre çeşidinin ortalama dane sayısının ise daha az değerde olduğu tespit edilmiştir (Çizelge 2). Çalışmadaki bulguların, Bayram ve ark. (2017)'nin 64 buğday çeşidini inceledikleri çalışmadaki ortalama dane sayısı (13.7-26.6 adet) değerleriyle ve Çağlar ve ark. (2005)'nin 25 ekmeklik çeşidini araştırdıkları çalışmadaki dane sayısı (19.930.4 adet) değerleriyle kısmen uyumlu olduğu belirlenmiştir. Özen ve Akman (2015)'ın 14 ekmeklik çeşidini inceledikleri çalışmadaki dane sayısı (21.9-45.9 adet) değerleri ile kısmen uyumlu olduğu, bazı genotiplere ait dane sayısının ise düşük olduğu saptanmıştır.

\subsection{Başakta Dane Verimi}

İncelenen buğday genotiplerinin başakta dane verimlerinin 0.19 ile $1.25 \mathrm{~g}$ arasında değiştiği, ortalama dane veriminin ise 0.66 g olduğu saptanmıştır. En düşük dane verimi P9 numaralı genotipte gözlenirken en yüksek dane veriminin ise P13 numaralı genotipe ait olduğu gözlemlenmiştir. Ahmetağa ve Cemre çeşitlerinin ortalama dane verimlerinin bütün genotiplerin dane verimi ortalamalarına göre düşük olduğu tespit edilmiştir (Çizelge 2). Çalışmadaki bulguların, Özen ve Akman (2015)'ın 14 ekmeklik buğday çeşidini inceledikleri çalışmadaki ortalama başakta dane verimi (0.9-1.9 g) değerleriyle, Aydoğan ve Soylu (2017)'nun 14 ekmeklik çeşidini araştırdıkları çalışmadaki ortalama başakta dane verimi (1.33-2.07 g) değerleriyle ve Naneli ve ark. (2015)'nın 25 ekmeklik buğday çeşidini inceledikleri çalışmadaki ortalama başakta dane verimi (1.23$1.97 \mathrm{~g}$ ) değerleri ile kısmen uyumlu olduğu, bazı genotiplerin dane veriminin ise düşük olduğu belirlenmiştir.

\subsection{Biyolojik Verim}

İncelenen buğday genotiplerinde ortalama biyolojik verim 2.18 ile $7.90 \mathrm{~g}$ arasında değişmiş olup genotiplerin ortalama biyolojik veriminin ise $3.75 \mathrm{~g}$ olduğu saptanmıştır. En düşük biyolojik verim P2 numaralı genotipte gözlenirken en yüksek biyolojik verim ise P17 genotipinde gözlemlenmiştir. Ahmetağa çeşidinin ortalama biyolojik veriminin bütün genotiplerin biyolojik verim ortalamasına göre düşük değerde olduğu, Cemre çeşidinin biyolojik veriminin ise yüksek olduğu tespit edilmiştir (Çizelge 2). Çalışmadaki bulguların Demirel ve ark. (2019)'nın çalışmalarında kullandıkları 5 buğday çeşidine ait ortalama biyolojik verim $(3.36 \mathrm{~g})$ değeriyle benzer olduğu tespit edilmiştir.

\subsection{Hasat İndeksi}

İncelenen buğdayların ortalama hasat indeksi oranı $\% 6.23$ ile \%30.25 arasında değişmiş olup genotiplerin ortalama hasat indeksi oranının ise \%19.34 olduğu saptanmıştır. En düşük hasat indeksi oranı P9 numaralı genotipte gözlenirken en yüksek hasat indeksi oranının ise P18 genotipine ait olduğu gözlemlenmiştir. Ahmetağa çeşidinin ortalama hasat indeksi oranı bütün genotiplerin hasat indeksi oranına göre çok yüksek değerde, Cemre çeşidinin hasat indeksi oranı ise çok düşük değerde olduğu tespit edilmiştir (Çizelge 2). Çalışmadaki bulguların, Özen ve Akman (2015)'in 14 ekmeklik buğday çeşidini inceledikleri çalışmadaki ortalama hasat indeksi değerleriyle (\%29.5-\%38) ve Naneli ve ark. (2015)'nın 25 ekmeklik çeşidini inceledikleri çalışmadaki hasat indeksi değerleriyle (\%27.5\%40.5) kısmen uyumlu olduğu, bazı genotiplerin hasat indeksi oranının ise düşük olduğu belirlenmiştir.

\subsection{Korelasyon Analizi}

Buğday genotiplerinde incelenen özellikler arasındaki ikili ilişkiler için korelasyon analizi sonuçları ve belirlenen korelasyon katsayıları Çizelge 3'de verilmiştir. Çizelgede görüldüğü üzere bitki boyu ile başak uzunluğu arasında önemli ve olumsuz yönde ilişki, bitki boyu ile hasat indeksi arasında çok önemli ve olumsuz yönde ilişki olduğu ortaya çıkmıştır. Başak uzunluğu ile dane sayısı, dane verimi ve biyolojik verim arasında çok önemli ve olumlu yönde ilişki olduğu saptanmıştır. Dane sayısı ile dane verimi ve biyolojik verim arasında çok önemli ve olumlu yönde ilişki olduğu, ayrıca dane sayısı ve hasat indeksi arasında önemli ve olumlu ilişki olduğu belirlenmiştir. Dane verimi ile biyolojik verim ve hasat indeksi arasında çok önemli ve olumlu yönde ilişki olduğu belirlenmiştir. Biyolojik verim ile hasat indeksi arasında ise çok önemli ve olumsuz yönde ilişki olduğu saptanmıştır (Çizelge 3). Mevcut çalışmanın özellikler arası ikili ilişki sonuçları, Aydoğan ve Soylu (2017)'nun başakta dane sayısı ile dane verimi arasındaki ilişkiyi önemli ve olumlu yönde olduğunu bildirdikleri çalışmayla, Demirel ve ark. (2019)'nın başakta dane verimi ile biyolojik verim arasındaki ilişkiyi ve başakta dane verimi ile hasat indeksi arasındaki ilişkiyi önemli ve olumlu yönde olduğunu bildirdikleri çalışmayla ve Yağmur ve Kaydan (2008)'ın başak uzunluğu ile başakta dane sayısı arasındaki ilişkiyi önemli ve olumlu yönde olduğunu bildirdikleri çalışmayla uyumlu olduğu belirlenmiştir. Ayrıca, Boru ve ark. (2019)'nın dane verimi ile dane sayısı arasındaki ilişkiyi önemli ve olumlu yönde tespit ettikleri çalışmayla uyumlu olduğu saptanmıştır. Dane verimine, başakta dane sayısı ve ağırlığının katkısının yüksek olduğu ve bu özelliklerin uygun bir seviyede olması gerektiği bildirilmektedir (Yağmur ve Kaydan, 2008). Bhutta (2006) dane sayısının, sürgün sayısının ve başak uzunluğunun başakta dane verimi (TV) ile ilişkili olduğunu bildirmiştir.

Çizelge 3. Incelenen özellikler arasındaki korelasyon katsayıları.

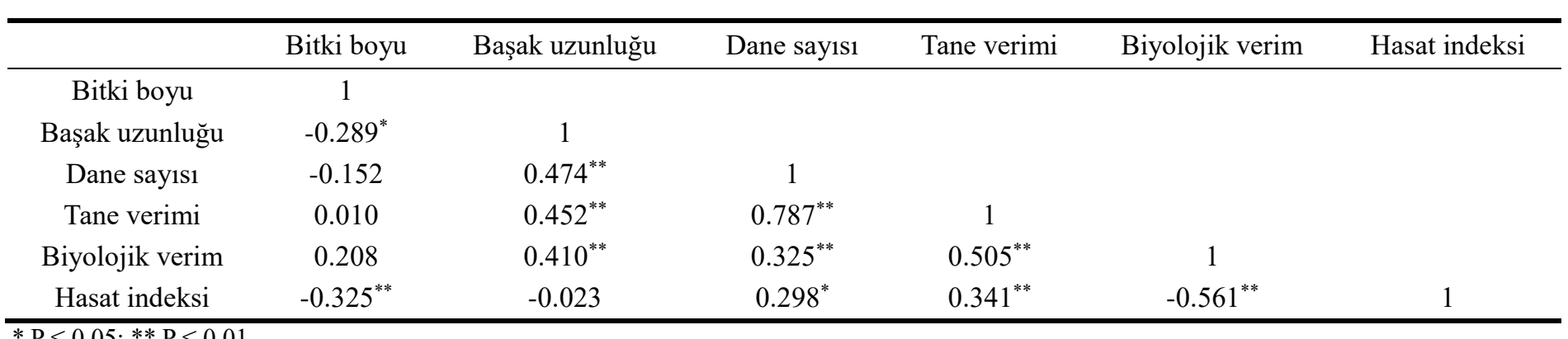




\subsection{Path Analizi}

İncelenen bitki boyu, başak uzunluğu, dane sayısı, biyolojik verim ve hasat indeksi özelliklerinin dane verimine doğrudan ve dolaylı yönden etkilerinin belirlendiği path analizi sonuçları ve path katsayıları ile oranları Çizelge 4'de verilmiştir. Bitki boyunun dane verimi üzerine doğrudan etkisi $(p=0.17)$ olumlu yönde ancak etki payı düşük (\%2.14) olarak hesaplanmıştır. Bitki boyu üzerinden dane verimine en yüksek dolaylı etkiyi dane sayısı $(p=-5.65, \% 71.67)$ olumsuz yönde oluşturmuştur. Başak uzunluğunun dane verimi üzerine doğrudan etkisi $(\mathrm{p}=$ 5.54) olumlu yönde ve etki payı en yüksek (\%42.63) olarak hesaplanmıştır. Başak uzunluğu üzerinden dane verimine en yüksek dolaylı etkiyi bitki boyu $(\mathrm{p}=-5.65, \% 39.02)$ olumsuz yönde gerçekleştirmiştir. Dane sayısının başakta dane verimi üzerine doğrudan etkisi ( $\mathrm{p}=0.38$ ) olumlu yönde ve etki payı orta seviye (\%6.27) olarak hesaplanmıştır. Dane sayısı üzerinden dane verimine en yüksek dolaylı etkiyi başak uzunluğu $(\mathrm{p}=2.73$, $\% 44.93$ ) olumlu yönde oluşturmuştur. Biyolojik verimin başakta dane verimi üzerine doğrudan etkisi $(p=0.73)$ olumlu yönde ve etki payı yüksek (\%10.09) olarak hesaplanmıştır. Biyolojik verim üzerinden dane verimine en yüksek dolaylı etkiyi bitki boyu ( $p=3.66, \% 50.36)$ olumlu yönde gerçekleştirmiştir. Hasat indeksinin dane verimi üzerine doğrudan etkisi $(p=0.69)$ olumlu yönde ve etki payı yüksek (\%8.08) olarak hesaplanmıştır. Hasat indeksi üzerinden dane verimine en yüksek dolaylı etkiyi bitki boyu ( $p=-5.82, \% 67.77)$ olumsuz yönde oluşturmuştur.

Çizelge 4. Incelenen özelliklerin dane verimine doğrudan ve dolaylı etkileri.

\begin{tabular}{|c|c|c|c|c|c|c|}
\hline & Doğrudan etki & & & Dolaylı etkile & & \\
\hline & Tane verimi & Bitki boyu & Başak uzunluğu & Dane say1s1 & Biyolojik verim & Hasat indeksi \\
\hline Bitki boyu & 0.17 & & -1.67 & -5.65 & 0.16 & -0.24 \\
\hline Oran $(\%)$ & 2.14 & & 21.13 & 71.67 & 2.02 & 3.04 \\
\hline Başak uzunluğu & 5.54 & -5.07 & & 0.19 & 0.31 & -1.89 \\
\hline Oran $(\%)$ & 42.63 & 39.02 & & 1.44 & 2.38 & 14.51 \\
\hline Dane sayısı & 0.38 & -2.50 & 2.73 & & 0.23 & 0.23 \\
\hline Oran $(\%)$ & 6.27 & 41.20 & 44.93 & & 3.75 & 3.86 \\
\hline Biyolojik verim & 0.73 & 3.66 & 2.34 & 0.12 & & -0.42 \\
\hline Oran $(\%)$ & 10.09 & 50.36 & 32.18 & 1.62 & & 5.74 \\
\hline Hasat indeksi & 0.69 & -5.82 & -1.50 & 0.13 & -0.44 & \\
\hline Oran $(\%)$ & 8.08 & 67.77 & 17.52 & 1.50 & 5.14 & \\
\hline
\end{tabular}

Mohsin ve ark. (2009), dane verimine en yüksek doğrudan etkiyi başakta dane sayısı ve başak uzunluğu karakterlerinin yaptığını vurgulamışlardır. Suleiman ve ark. (2014), bin dane ağırlığı ve başakta dane sayısı karakterlerinin dane verimi üzerine path sonucunun önemli ve doğrudan etkiye sahip olduğunu bildirmişlerdir. Özlem Kurt Polat ve ark. (2015), dane verimine en yüksek doğrudan etkiyi başakta dane ağırlığı ve başakta dane sayısı karakterlerinin yaptığını ve bitki boyu, başak boyu ve bin dane ağırlığı karakterlerinin dane verimini olumlu yönde etkilemede seleksiyon kriteri olarak alınabileceğini belirtmişlerdir. Başak boyu özelliklerinin seleksiyon kriteri olarak kullanılabileceği bildirilmiştir (Ahmad ve ark., 2018). Boru ve ark. (2019), dane verimine olumlu yönde ve en yüksek doğrudan etkiye sahip karakterleri sırasıyla başakta dane ağırlığ ve başakta dane sayısı olduğunu belirtmiş̧lerdir.

\subsection{Kümeleme ve Biplot Analizleri}

Her bir genotipin incelenen özelliklerine göre dahil oldukları grupları belirleyebilmek için hiyerarşik kümeleme yapılmıştır (Şekil 1). Kümeleme analizi sonucuna göre genotipler iki kümeye (A ve B) ayrılmıştır. Cemre çeşidinin de dahil olduğu A kümesinde, Cemre çeşidine yakın özellikler gösteren genotiplerin P8, P9 ve P17 olduğu saptanmıştır. Ahmetağa çeşidinin de dahil olduğu B kümesinde P2, P3, P13 ve P18 numaralı genotiplerin bulunduğu belirlenmiştir. Ahmetağa çeşidine özellikler yönünden en yakın benzerlik gösteren genotiplerin P2 ve P3 olduğu tespit edilmiştir. İncelenen özellikler yönünden irdelenen genotiplerin kümeleme analizi yöntemiyle benzerlik oranlarının ve oluşturdukları grupların belirlenmesi sayesinde, genotiplerin birbirine olan yakınlığı ve uzaklığı tespit edilebilmektedir. Buğday genotipleri agronomik ve kalite özellikleri yönünden kümeleme analizi ile değerlendirilebilmektedir (Kahrıman ve Egesel, 2011; Demirel ve ark., 2019). 


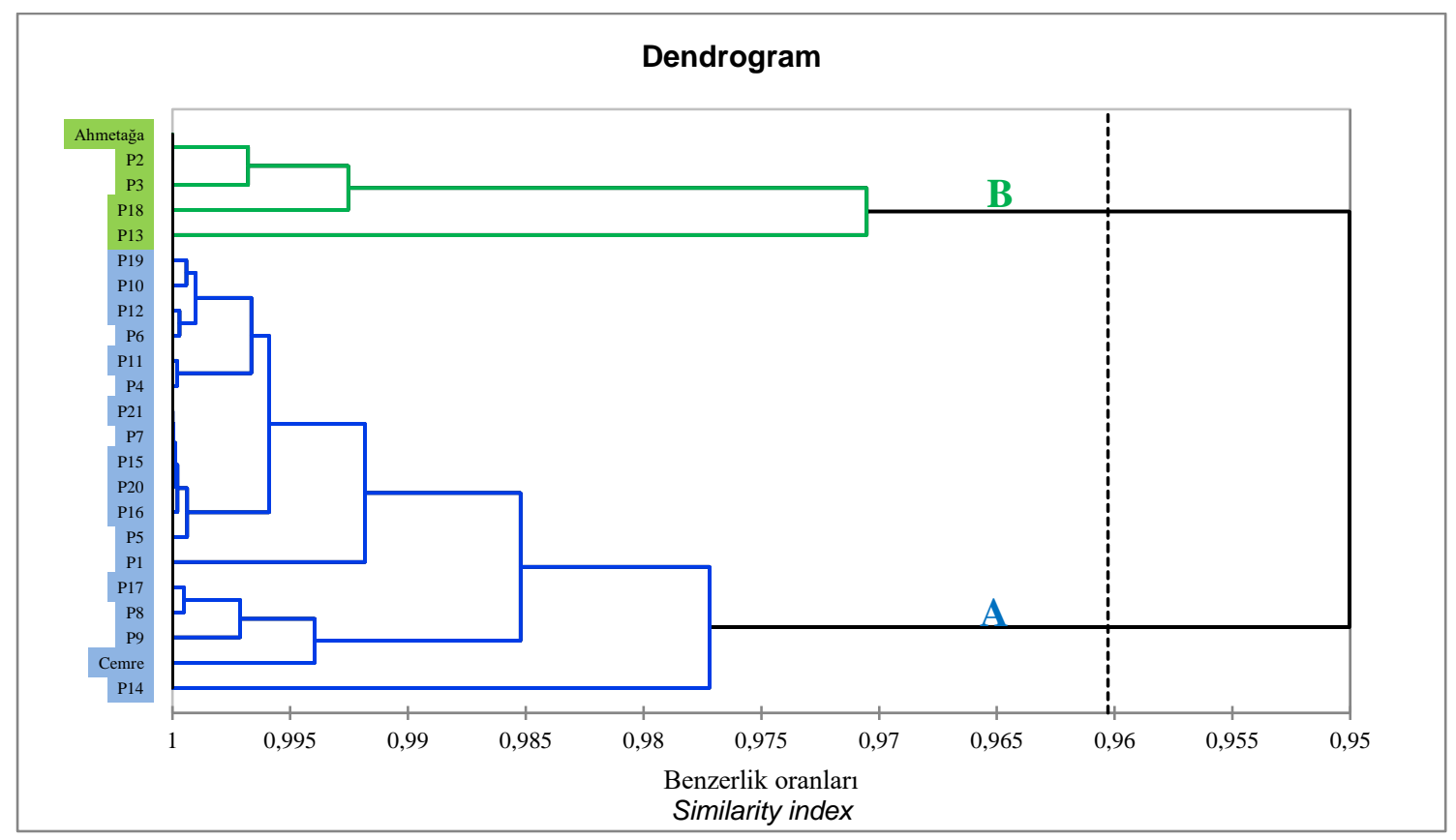

Şekil 1. Incelenen özelliklerden yararlanılarak oluşturulan kümeleme sonucu.

Genotipler ile özelliklerin ilişkisini görsel olarak gösteren biplot analizi sonucu Şekil 2'de verilmiştir. Biplot analizi sonucuna göre F1 toplam varyasyonun \%37.31'ini açıklarken, F2'de ise toplam varyasyonun \%36'sınının açıklandığ görülmekte olup F1 ve F2 toplam varyasyonun \%73.32'sini açıklamaktadır. Araştırmacılar tarafından kullanılan Biplot analizi yöntemi, özellikler arası ilişkileri görsel olarak daha net ortaya koymakta ve analiz sonuçlarının kolay değerlendirilmesini sağlamaktadır (Akçura ve Topal, 2008; Demirel ve ark., 2019). Çalışmadaki bulguların, F1 ve F2'nin toplam varyasyonun \%70.31'ini açıkladığını bildiren Aktaş ve ark. (2017)'nın sonuçlarıyla ve F1 ve F2'nin toplam varyasyonun \%72.08'inin açıklandığını rapor eden Demirel ve ark. (2019)'nın bildirişleriyle uyumlu olduğu saptanmıştır. Toplam varyasyonun \%65.48'inin açıklandığını ortaya koyan Tekdal ve ark. (2014)'nın ve toplam varyasyonun \%51'ini açıkladığını bildiren Kılıç ve ark. (2012)'nın sonuçlarından ise yüksek olduğu tespit edilmiştir.

Şekil 1'de A kümesinde gruplanan Ahmetağa, P2 ve P3 genotipleri hasat indeksi bakımından diğer genotiplerden üstün bulunmuştur (Şekil 2). Diğer genotiplere göre P4 ve P11 numaralı genotiplerin bitki boyu yönünden öne çıkmış oldukları saptanmıştır. Biyolojik verim yönünden öne çıkan genotiplerin ise P8 ve P17 numaralı genotipler olduğu tespit edilmiştir (Şekil 2).

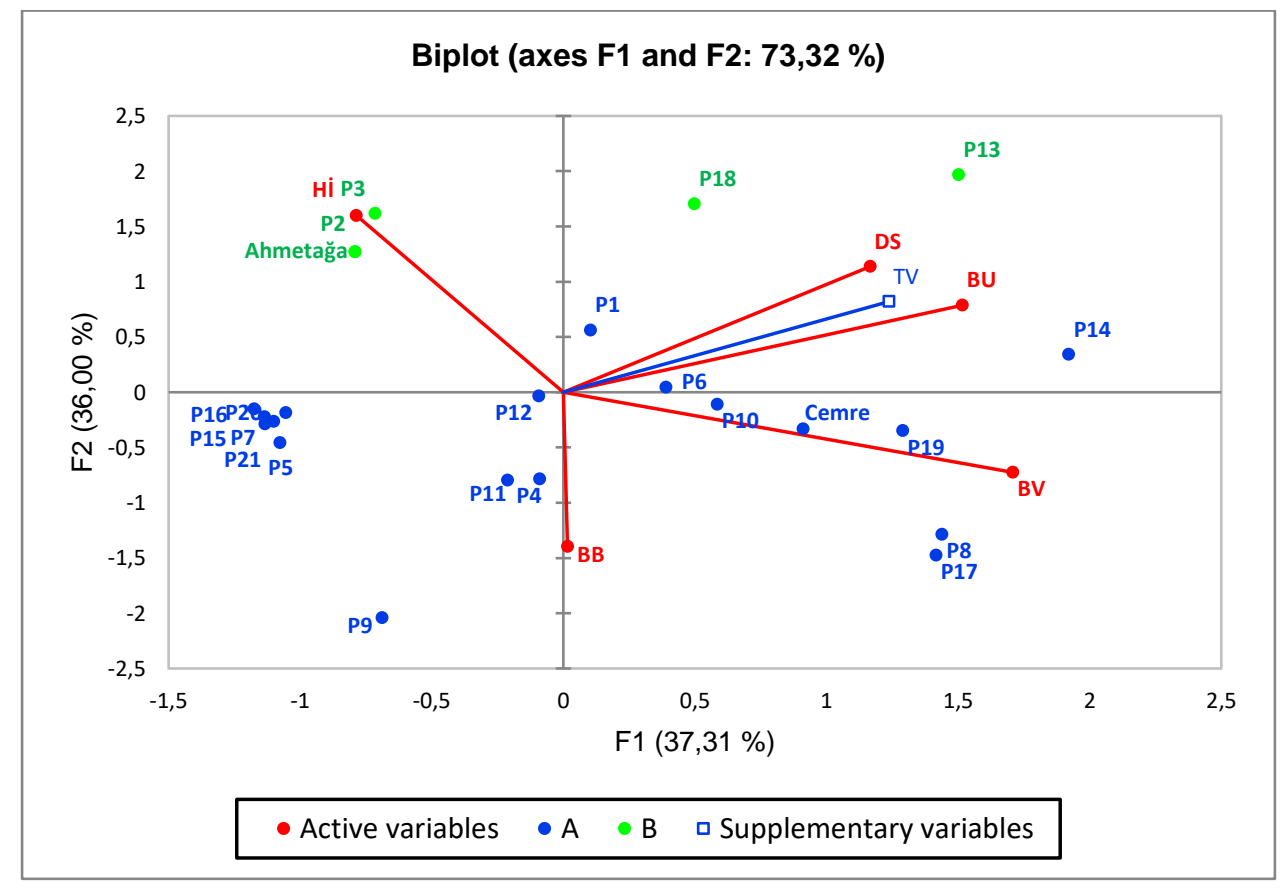

Şekil 2. Incelenen özellikler ile genotiplerin konumlarını gösteren biplot grafiği. 


\section{Sonuç}

Genotiplerin önemli düzeyde geniş varyasyon gösterdiği bu çalışma sonucunda, incelenen genotiplerde dane verimini olumlu yönde ve doğrudan etkileyen en önemli özelliğin başak uzunluğu olduğu ve dane verimi ile başak uzunluğu arasında olumlu bir korelasyon olduğu belirlenmiştir. Dane verimine başak uzunluğu üzerinden en yüksek dolaylı etkiyi ise bitki boyu özelliğinin verdiği, bitki boyu ile başak uzunluğu arasında önemli seviyede olumsuz yönde korelasyon olduğu saptanmıştır. Sonuç olarak bitki boyunun kısa ve başak uzunluğunun yüksek olduğu genotiplerde dane veriminin daha yüksek olduğu tespit edilmiştir. Dane verimi yönünden seleksiyon için P13, P14 ve P19 numaralı genotiplerin öne çıktığ belirlenmiş olup, bu genotipler üzerinden çalışmaların devam edilmesi gerektiği sonucuna varılmıştır. Ayrıca, genotipler üzerinde incelenen özelliklerin sonraki yıllarda da devam ettirilmesinin daha uygun olacağı kanaatine varılmıştır.

\section{Teşekkür}

Makale yazarları arasında herhangi bir çıkar çatışması bulunmamaktadır. FD, AMK ve BY çalışmayı tasarlayarak denemeleri kurmuş, FD çalışmayı yürütmüş ve verileri analiz etmiş, FD ve BY makaleyi yazmıştır. $\mathrm{Bu}$ araştırma Iğdır Üniversitesi Bilimsel Araştırma Projeleri Koordinatörlüğünün desteği ile (2017-FBE-D01) gerçekleştirilmiştir. Desteklerinden dolayı teşekkür ederiz. Bu makale Fatih DEMIREL'in Doktora tez çalışmasından üretilmiştir.

\section{Kaynakça}

Addinsoft, S. X. V. (2015). 01: Data Analysis and Statistics Software for Microsoft Excel. Addinsoft: Paris, France.

Ahmad, T., Kumar, A., Pandey, D., \& Prasad, B. (2018). Correlation and path coefficient analysis for yield and its attributing traits in bread wheat (Triticum aestivum L. em Thell). Journal of Applied and Natural Science, 10(4), 10781084.

Akçura, M., \& Topal, A. (2008). İç Anadolu Bölgesi yerel ekmeklik buğday populasyonlarından seçilen saf hatların dane verimi ve kalite özellikleri yönünden bazı tescilli çeşitlerle karşılaştırılması. Ülkesel Tahıl Sempozyumu, Selçuk Üniversitesi Ziraat Fakültesi, Konya.

Akgün, İ., Kaya, M., \& Altındal, D. (2007). Isparta ekolojik koşullarında bazı tritikale hat/çeşitlerinin verim ve verim unsurlarının belirlenmesi. Akdeniz Üniversitesi Ziraat Fakültesi Dergisi, 20(2), 171-182.

Aktaş, H., Erdemci, İ., Karaman, M., Kendal, E., \& Tekdal, S. (2017). Bazı kışlık ekmeklik buğday genotiplerinin dane verimi ve bazı kalite özellikleri bakımından GGE biplot analiz yöntemi ile değerlendirilmesi. Türk Doğa ve Fen Dergisi, 6(1), 43-51.

Aydın, N., Bayramoğlu, H. O., Mut, Z., \& Özcan, H. (2005). Ekmeklik buğday (Triticum aestivum L.) çeşit ve hatlarının karadeniz koşullarında verim ve kalite özelliklerinin belirlenmesi. Ankara Üniversitesi Ziraat Fakültesi Tarım Bilimleri Dergisi, 11(3), 257-262.

Aydoğan, S., \& Soylu, S. (2017). Ekmeklik buğday çeşitlerinin verim ve verim öğeleri ile bazı kalite özelliklerinin belirlenmesi. Tarla Bitkileri Merkez Araştırma Enstitüsü Dergisi, 26(1), 24-30.
Bayram, S., Öztürk, A., \& Aydın, M. (2017). Ekmeklik buğday genotiplerinin Erzurum koşullarında dane verimi ve verim unsurları yönünden değerlendirilmesi. Yüzüncü Y1l Üniversitesi Tarım Bilimleri Dergisi, 27(4), 569-579.

Bhutta, W. M. (2006). Role of some agronomic traits for grain yield production in wheat (Triticum aestivum L.) genotypes under drought conditions. Revista UDO Agrícola, 6(1), 1119.

Boru, K., Yıldırım, S., \& Çifci, E. A. (2019). Ekmeklik buğday genotiplerinde verim ve verim öğelerinin korelasyon ve path analizi ile incelenmesi. Türk Tarım ve Doğa Bilimleri Dergisi, 6(3), 379-387.

Çağlar, Ö., Öztürk, A., \& Bulut, S. (2006). Bazı ekmeklik buğday çeşitlerinin Erzurum ovası koşullarına adaptasyonu. Atatürk Üniversitesi Ziraat Fakültesi Dergisi, 37(1), 1-7.

Dağüstü, N. (2008). Genetic analysis of grain yield per spike and some agronomic traits in diallel crosses of bread wheat (Triticum aestivum L.). Turkish Journal of Agriculture and Forestry, 32(4), 249-258.

Demirel, F., Gurcan, K., \& Akar, T. (2019). Clustering analysis of morphological and phenological data in einkorn and emmer wheats collected from Kastamonu region. International Journal of Scientific and Technological Research, 5(11), 25-36.

Heun, M., Schäfer-Pregl, R., Klawan, D., Castagna, R., Accerbi, M., Borghi, B., \& Salamini, F. (1997). Site of einkorn wheat domestication identified by DNA fingerprinting. Science, 278(5341), 1312-1314.

Kahrıman, F., \& Egesel, C. Ö. (2011). Farklı ekmeklik buğday çeşitlerinin agronomik ve kalite özellikleri bakımından değerlendirilmesi. Ordu Üniversitesi Bilim ve Teknoloji Dergisi, 1(1), 22-35.

Kılıç, H., Aktaş, H., Kendal, E., \& Tekdal, S. (2012). İleri kademe ekmeklik buğday (Triticum aestivum L.) genotiplerinin biplot analiz yöntemi ile değerlendirilmesi. Türk Doğa ve Fen Dergisi, 1(2), 132-139.

Kırtok, Y. (1997). Genel Tarla Bitkileri. Adana: Çukurova Üniversitesi Ziraat Ders Kitabı No: 30, Adana.

Lev-Yadun, S., Gopher, A., \& Abbo, S. (2000). The cradle of agriculture. Science, 288(5471), 1602-1603.

Mohsin, T., Khan, N., \& Naqvi, F. N. (2009). Heritability, phenotypic correlation and path coefficient studies for some agronomic characters in synthetic elite lines of wheat. Journal of Food Agriculture and Environment, 7(3/4), 278282.

Naneli, İ., Sakin, M. A., \& Kıral, A. S. (2015). Tokat-Kazova şartlarında bazı ekmeklik buğday (Triticum aestivum L.) çeşitlerinin verim ve kalite özelliklerinin belirlenmesi. Gaziosmanpaşa Üniversitesi Ziraat Fakültesi Dergisi, 32(1), 91-103.

Okuyama, L. A., Federizzi, L. C., \& Barbosa Neto, J. F. (2004). Correlation and path analysis of yield and its components and plant traits in wheat. Ciência Rural, 34(6), 1701-1708.

Orhan, H., \& Kaşıç̧ı, D. (2002). Path, korelasyon ve kısmi regresyon katsayılarının karşılaştırılmalı olarak incelenmesi. Hayvansal Üretim, 43(2), 68-78.

Özen, S., \& Akman, Z. (2015). Yozgat ekolojik koşullarında bazı ekmeklik buğday çeşitlerinin verim ve kalite özelliklerinin belirlenmesi. Süleyman Demirel Üniversitesi Ziraat Fakültesi Dergisi, 10(1), 35-43.

Özlem Kurt Polat, P., Aydoğan Çifci, E., \& Yağdı, K. (2015). Ekmeklik buğday (Triticum aestivum L.)'da dane verimi ile 
bazı verim ögeleri arasındaki ilişkilerin saptanması. Journal of Agricultural Sciences, 21(3), 355-362.

Sabaghnia, N., \& Janmohammadi, M. (2014). Interrelationships among some morphological traits of wheat (Triticum aestivum L.) cultivars using biplot. Botanica, 20(1), 19-26.

Suleiman, A. A., Nganya, J. F., \& Ashraf, A. (2014). Correlation and path analysis of yield and yield components in some 221 cultivars of wheat (Triticum aestivum L.) in Khartoum state, Sudan. Journal of forest products \& industries, 3(4), 198-203.

Tekdal, S., Kendal, E., \& Ayana, B. (2014). İleri kademe makarnalık buğday hatlarının verim ve bazı kalite özelliklerinin biplot analiz yöntemi ile değerlendirilmesi. Türk Tarım ve Doğa Bilimleri Dergisi, 1(3), 322-330.

Tosun, O., \& Yurtman, N. (1973). Ekmeklik buğdaylarda verime etkili başlıca morfolojik ve fizyolojik karakterler arasındaki ilişkiler. Ankara Üniversitesi Ziraat Fakültesi Yıllığı, 23, 434-441.

Tugay, M. E. (1978). Dört Ekmeklik Buğday Çeşidinde Ekim Siklığı ve Azotun Verim, Verim Komponentleri ve Diğer Bazı Özellikler Üzerine Etkileri. Ege Üniversitesi Ziraat Fakültesi Yayınları, 316.

Yağmur, M., \& Kaydan, D. (2008). Kışlık buğday dane verimi, verim öğeleri ve fenolojik dönemler arasındaki ilişkiler. Harran Üniversitesi Ziraat Fakültesi Dergisi, 12(4), 9-18. 